\title{
Heat-Induced Resistance of Apple Leaves Against Alternaria mali and Its Host-Specific Toxins*
}

\author{
Islam Din KhaN**, Keisuke Kонмото** \\ and Syoyo Nishimura** \\ Islam Din KHAN**・甲元啓介**・西村正暘**：リンゴ斑点落葉病菌と \\ その宿主特異的毒素作用に対する熱処理リンゴの抵抗性
}

Recently, we have reported the presence of multiple host-specific toxins in the culture filtrates of Alternaria mali Roberts ${ }^{1}$. Two of the toxins, AM-toxin ${ }^{2)}$ (Alternariolide ${ }^{3}$ ) and $\mathrm{II}^{4}$, have been isolated in crystalline form and their chemical structures have been confirmed as cyclic depsipeptides closely related to each other ${ }^{4}$. The AMtoxin I (major toxin) induces a rapid and marked loss of electrolytes from the susceptible leaf-tissues, which later depict a typical veinal necrosis ${ }^{1)}$. On younger leaves of the susceptible cv. of apple, "Indo", the threshold concentration inducing the electrolyte loss was $10^{-9} \mathrm{M}$, while that on the resistant cv. "Jonathan", it was $10^{-5} \mathrm{M}$. Informations on host-specificity of such toxins appear to be useful for understanding the specific parasitism in plant disease.

A thermobiological approach has recently provided some valuable informations. In the combination of Alternaria kikuchiana toxin (AK-toxin) and susceptible cr. of Japanese pear, a partial protection of the susceptible thost by thermal treatment was evident when measured by toxin-induced necrosis, suggesting that a hypothetical toxin binding site in susceptible tissues could be changed in its configuration by a mild heat treatment ${ }^{5}$. The same physiological event was strengthened by the recent confirming of Steiner and Byther ${ }^{6}$ ) with sugarcane and helminthosporoside. As little is known about thermo-physiology of the action of AM-toxins, we have attempted to examine the thermal effect on toxin-induced necrosis and electrolyte loss in susceptible apple. Preliminary report has been published ${ }^{7)}$.

Virulent isolates of $A$. mali (0-92) and A. kikuchiana (K-22), and "Orei" as a susceptible cv. and "Jonathan" as a resistant cv. of apple were employed during the

*: Supported in part by grants No. 736005 (1972) and No. 936004 (1974) from Scientific Research Expenditure, Ministry of Education, Japan.

**: Faculty of Agriculture, Tottori University, Tottori, Jappan. 鳥取大学農学部

The sinior author was a recipient of a Post-doctoral Fellowship of JSPS. His present address: Division of Applied Biology, Jawaharlal Nehru University, Imphal, Manipur, India.

1) Kohmoto, K., Khan, I. D., Renbutsu, Y., Taniguchi, T. and Nishimura, S. Physiological Plant Pathology (in press). 2) Ueno, T., Hayashi, Y., Nakashima, T., Fukami, H., Nishimura, S., Kohmoto, K. and "Sekiguchi, A. (1975). Phytopathology $65: 82-83 . \quad$ 3) Okuno, T., Ishita, Y., Sawai, K. and Matsumoto, T. (1974). Chemistry Letters: 635-638. 4) Nishimura, S., Kohmoto, K., Otani, H., Fukami, H. and Ueno, T. (1974). Abstr. No. 53, 1st Intersectional Congress of International Association of Microbiological Society, Tokyo. 5) Otani, H., Nishimura, S. and Kohmoto, K. (1974). Ann. Phytopath. Soc. Japan 40:59-66. 6) Steiner, W. G. and Byther, R. S. (1974). Proc. Am. Phytopath. Soc. 1: 34 (Abstr.). 
Table 1. Effect of heat-treatment on toxin-induced veinal necrosis of leaves from host plants

\begin{tabular}{lccc}
\hline \multirow{2}{*}{ Cultivar } & Toxin conc. $(\mathrm{M})$ & Necrotic area $\left(\mathrm{cm}^{2}\right)$ \\
\cline { 3 - 4 } & & Unheated & Heated $^{\mathrm{a})}$ \\
\hline Orei $^{\mathrm{b})}$ & $10^{-5}$ & 6.59 & 3.28 \\
& $10^{-7}$ & 5.70 & 0.31 \\
Jonathanc) & $10^{-4}$ & 5.14 & 0 \\
Nijisseikid) & $10^{-5}$ & 0.17 & 0 \\
\hline
\end{tabular}

a) Tissues were held in water at $55 \mathrm{C}$ for $2 \mathrm{sec}$.

c) Resistant cv. of apple

b) Susceptible cv. of apple

d) Susceptible cv. of Japanese pear.

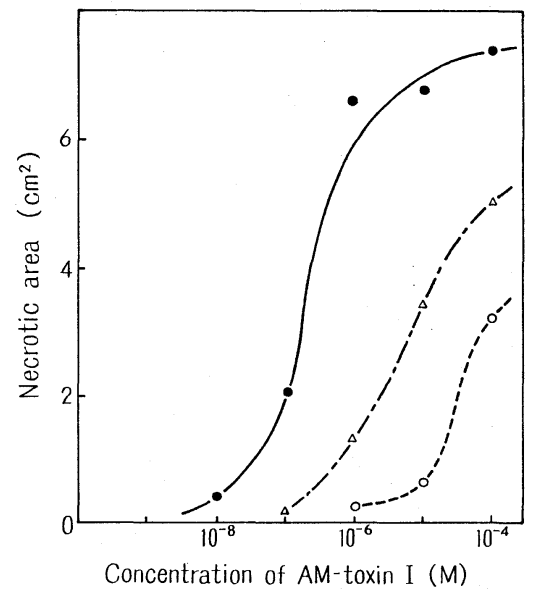

Fig. 1. Protective effect of mild heat on the necrotic response of leaves from susceptible cv. "Orei" of apple.

-- - : Unheated, -. $\triangle \cdot-$ : Heated (55 C, 2 sec), $\cdots \circ \cdots$ : Heated ( $55 \mathrm{C}, 3 \mathrm{sec}$ ).

investigation. "Nijisseiki" cv. of Japanese pear has recently been reported to be susceptible to the attack of $A$. mali ${ }^{7,8}$. "Nijisseiki" cv. was also employed for comparison. Leaves from all these plants were immersed for $2 \mathrm{sec}$ in a water bath at $55 \mathrm{C}$. The pre-heated leaves and untreated controls were wounded slightly in the center with a needle, and a drop $(20 \mu \mathrm{l})$ of AMtoxin I, which was prepared as described previously, were placed on the wound ${ }^{1}$. After $48 \mathrm{hr}$ incubation at $25 \mathrm{C}$ in a moist chamber, necrotic area of the leaves was measured. The flash treatment with mild heat gave about $50 \%$ reduction in necrotic area at relatively higher concentration of AM-toxin $\mathrm{I}\left(10^{-5} \mathrm{M}\right)$ and almost complete protection at $10^{-7} \mathrm{M}$ on the susceptible apple leaves (Table $1 \&$ Fig. 1). When heatexposure time was increased to $3 \mathrm{sec}$, this protectivee effect became more evident, and a sigmoidal mode of action for the toxin concentration vs. necrotic area was observed to shift to the right (Fig. 1). Higher concentrations over $10^{-5} \mathrm{M}$ of AM-toxin I induced veinal necrosis even on the resistant apple and "Nijisseiki" cv. of Japanese pear. However, no necrotic indications were observable on these tissues, when they were pre-treated with the mild heat (Table 1). This means that by the brief heat-treatment the resistant hosts also changed to more or less completely insensitive ones to the attack of AM-toxin I. The toxin-insensitivity by thermal treatment can be understood reasonably by the genetic data ${ }^{9)}$ that "Jonathan", even though a resistant cv., lacks a complete set of the cumulative multiple genes for the disease resistance, in contrast to the case of immune cv. of Japanese pear against A. kikuchiana, where the disease

7) Khan, I. D., Renbutsu, Y., Kohmoto, K. and Nishimura, S. (1973). Ann. Phytopath. Soc. Japan 39: 161 (Abstr.). 8) Sekiguchi, A., Ueno, T. and Nishimura, S. (1974). Ann. Phytopath. Soc: Japan 39 : 175 (Abstr.). 9) Tsuchiya, S., Yoshida, and Haniuda, T. (1967). Bull. Hort. Res. Stan. Japan C 5: 9-19. 
resistance is controlled by a single recessive gene pair ${ }^{10)}$.

Another line of evidence for the toxin-insensitivity of the suscepts was obtained as follows: Holding tissues in water at $55 \mathrm{C}$ for $2 \mathrm{sec}$ gave protection against the toxin-induced loss of electrolytes from the tissues of the susceptible cv. treated with AM-toxin $\mathrm{I}\left(10^{-6} \mathrm{M}\right)$, but did not affect the resistant $\mathrm{cv}$. treated with the toxin or water as control.

Three response types of toxin activity-temperature relations have been already reported: The AK-toxin was found to have a clear optimum temperature of activity $(25-28 \mathrm{C})^{11)}$, while the toxicity of Helminthosporium carbonum toxin against susceptible corn plants was enhanced with a rise in temperature $(5 \text { to } 37 \mathrm{C})^{12}$. However, variation in temperature over a wide range $(5-37 \mathrm{C})$ did not affect the activity of the Helminthosporium victoriae toxin ${ }^{13}$.

To elucidate the relation between temperature and the activity of AM-toxins, a given amount of the toxins and culture filtrates of $A$. mali was applied to crosswounded leaves of the susecptible host. An acidic, major toxin (tentatively named as AM-toxin A) and netural, major toxins (presumably a complex of AM-toxin I \& II) from cultures of A. mali were prepared as described

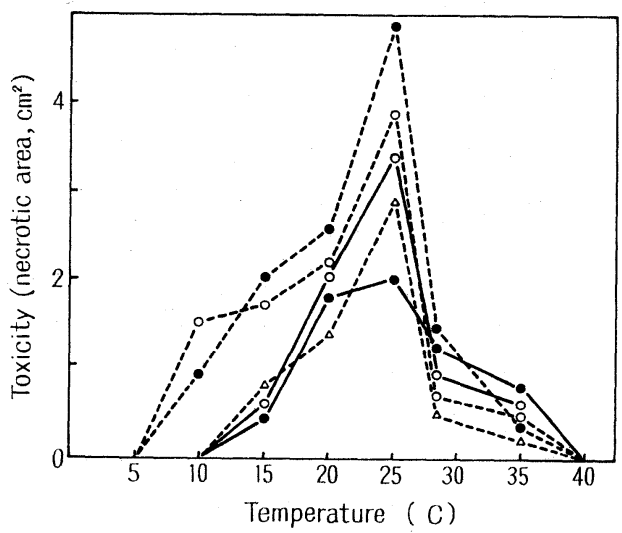

Fig. 2. Effect of temperature on the veinal necrosis induced by the culture filtrates of Alternaria mali (0-92) and A. kikuchiana $(\mathrm{K}-22)$, and their hostspecific toxins.

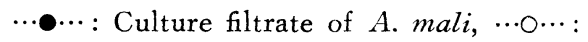
AM-toxin A, $\cdots \triangle \cdots:$ A complex of AMtoxin I \& II, - - : Culture filtrate of $A$. kikuchiana, -O-: AK-toxin.

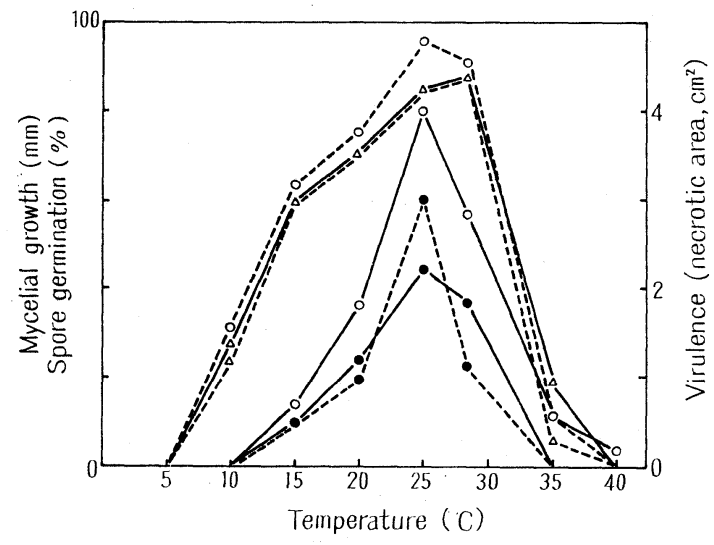

Fig. 3. Effect of temperature on mycelial growth, spore germination, and virulence of $A$. mali and A. kikuchiana. Mycelial growth was measured in petri plates on potato-dextrose agar after 7 day-incubation at constant temperatures given above. Rate of spore germination was determined by incubating the spore suspensions on glass-slides at given temperatures for $5 \mathrm{hrs}$. To assess virulence of the pathogens, spores were sprayed on susceptible leaves of apple and Japanese pear, respectively, which were placed at given temperatures to allow disease development under moist conditions. Necrotic area was measured after $48 \mathrm{hr}$-incubation.

... A. mali (0-92), - : A. kikuchiana (K-22), • : Virulence (necrotic area), $O$ : Spore germination, $\triangle:$ Mycelial growth.

10) Kozaki, I. (1973). Bull. Hort. Res. Stan. Japan A $12: 17-27$. 11) Otani, H., Nishimura, S. and Kohmoto, K. (1972). Jour. Fac. Agri. Tottori Univ. 7:5-12. 12) Kuo, M. S. and Scheffer, R. P. (1969). Phytopathology. 59: 1779-1782. 13) Scheffer, R. P. and Pringle, R. B. (1964). Phytopathology $54: 832-835$. 
previously ${ }^{1}$. Partially purified AK-toxin ${ }^{5}$ as well as the culture filtrate of A. kikuchiana were also employed for comparison. The treated leaves were incubated in moist chambers at specified temperatures from 5 to $40 \mathrm{C}$ to develop toxin-induced necrosis. Necrotic area was read after $48 \mathrm{hr}$-incubation. Results in Fig. 2 show that consistently a clear cut optimal temperature for toxicosis by AM-toxins and culture filtrate of $A$. mali was found to be $25 \mathrm{C}$, and their mode of temperature-toxin activity relation was similar to that of AK-toxin. The optimal temperature $(25 \mathrm{C})$ coincided with the temperature optima for pathogenicity expression and growth of both the pathogens (Fig. 3). The heat-induced insensitivity of the suscepts to the AM-toxins is suggestive of the idea that environmentally encountered high temperatures over $30 \mathrm{C}$ for several hrs would change sensitive tissues to resistant ones, occasionally and temporarily. Mid-summer decline in development of Alternaria blotch of apple and black spot of Japanese pear might be in part ascribed not only to the retardation in growth of the pathogens, but also to the acquired toxin-insensitivity of the suscept plants at such high temperatures.

We thank Drs. H. Fukami and T. Ueno, Kyoto University for kindly providing crystalline AM-toxin I under a Cooperative Research Plan with us. We appreciate Mr. H. Otani for his valuable discussions and Mr. T. Taniguchi for technical assistance. 